\title{
PENGARUH STRATEGI PEMBELAJARAN MENGGUNAKAN MEDIA INTERNET DAN KEMAMPUAN BERPIKIR SEKUENSIAL TERHADAP HASIL BELAJAR IPS
}

\author{
Irham Lubis dan Abdul Hasan Saragih \\ SMP Negeri 4 Sei Suka, Medan dan PPs Universitas Negeri Medan \\ irham.lubis@gmail.com
}

\begin{abstract}
Abstrak: Penelitian ini bertujuan untuk mengetahui perbedaan hasil belajar IPS siswa yang diajar dengan strategi pembelajaran berbasis masalah dan ekspositori menggunakan media internet, mengetahui perbedaan hasil belajar IPS siswa yang memiliki memiliki kemampuan berpikir sekuensial abstrak dengan sekuensial konkret, dan mengetahui interaksi antara strategi pembelajaran menggunakan media internet dengan kemampuan berpikir terhadap hasil belajar IPS. Metode penelitian menggunakan quasi eksperimen dengan desain penelitian faktorial $2 \times 2$, sedangkan teknik analisis data menggunakan ANAVA dua jalur pada taraf signifikansi $\alpha=0.05$. Hasil penelitian diperoleh: hasil belajar IPS siswa yang diajar dengan strategi pembelajaran berbasis masalah lebih tinggi daripada strategi pembelajaran ekspositori menggunakan media internet; hasil belajar IPS siswa yang memiliki kemampuan berpikir sekuensial abstrak lebih tinggi daripada kemampuan berpikir sekuensial konkret; dan terdapat interaksi antara strategi pembelajaran menggunakan media internet dengan kemampuan berpikir sekuensial dalam mempengaruhi hasil belajar IPS siswa.
\end{abstract}

Kata Kunci: strategi pembelajaran berbasis masalah menggunakan media internet dan media internet, kemampuan berpikir sekuensial abstrak dan sekuensial konkret

\begin{abstract}
This study aims to determine the differences in the results of social studies students taught with problem-based learning strategies and expository uses the internet, find the differences between the results of social studies students who have the ability to think sequential sequential abstract with the concrete, and the interaction between learning strategy using the internet with ability to think on learning outcomes IPS. Using a quasi-experimental research method with $2 \times 2$ factorial study design, data analysis techniques while using ANOVA two lanes at the significance level $\square=0: 05$. The results were obtained: the results of social studies students taught with problem-based learning strategy is higher than expository teaching strategy using the internet; IPS learning outcomes of students who have the ability to think abstract sequential higher than concrete sequential thinking skills; and there is an interaction between learning strategy using the internet with sequential thinking skills in influencing student learning outcomes IPS.
\end{abstract}

Keywords: problem-based learning strategies using the internet and the internet, the ability to think abstractly and sequential concrete sequential

\section{PENDAHULUAN}

Salah satu rumpun pembelajaran yang dilaksanakan di SMP adalah rumpun ilmu sosial yang mengkaji interaksi antara manusia dan masyarakat serta lingkungan melalui konsep Geografi, ekonomi dan sejarah. Kecakapan atau kemahiran dalam pengetahuan sosial yang diharapkan dapat tercapai dalam pembelajaran ilmu sosial (IPS) dituangkan dalam standar kompetensi berupa kemampuan memahami konsep-konsep pengetahuan sosial baik geografi,sejarah dan ekonomi yang merupakan bagian dari IPS . Konsep-konsep yang terdapat dalam ilmu pengetahuan sosial antara lain interaksi, saling ketergantungan, kesinambungan dan perubahan (continuity and Change), keberagaman, konflik dan konsensus, pola, tempat, kekuasaan, nilai kepercayaan dan keadilan dan pemerataan (Solihatin dan Raharjo 2008:15).

Setelah mempelajari IPS siswa diharapkan mampu bersosialisasi dengan lingkungan sekitarnya baik terhadap lingkungan alam dan lebih khusus lagi dengan sesama manusia dalam kelompok masyarakat, mampu bertindak sebagai individu yang mandiri dan bertanggung jawab di masyarakat dan yang terpenting siswa memiliki rasa cinta terhadap 
bangsa, negara dan tanah air yang diwujudkan dalam tindakan nyata, mampu mengkomunikasikan gagasan dan kemampuan yang optimal dan memiliki cara berpikir logis dan bernalar tinggi dalam memecahkan persoalan-persoalan melalui pengaplikasian kecakapan yang berkaitan dengan kehidupan sosial dilingkungannya dalam kehidupan seharihari. Namun pada kenyataannya standar kompetensi yang diharapkan dapat diperoleh siswa setelah mempelajari mata pelajaran IPS belum dapat tercapai secara optimal. Hal ini sesuai pula dengan pendapat yang dikemukakan Nurhadi (2004:2) bahwa hasil pembelajaran di sekolah dasar dan menengah di Indonesia menunjukkan ketidakmampuan anak-anak menghubungkan antara yang dipelajari dan bagaimana pengetahuan itu dimanfaatkan untuk memecahkan persoalan sehari-hari.

Meskipun telah banyak upaya yang dilakukan oleh pemerintah dan pihak sekolah, namun dalam kenyataannya mutu pendidikan masih tetap rendah. Rendahnya mutu pendidikan ini tercermin pada hasil belajar siswa yang salah satu tolak ukurnya adalah Ujian Akhir Sekolah (UAS). Hal ini terjadi di SMP Negeri 4 Sei Suka Kabupaten Batu Bara ,bahwa hasil belajar siswa sangat rendah termasuk pada mata pelajaran IPS yaitu nilainya berada dibawah nilai ketuntasan belajar (75). Data yang diperoleh dari kantor Tata Usaha, dapat dilihat bahwa nilai rata-rata UAS siswa SMP Negeri 4 Sei Suka Kabupaten Batu Bara untuk mata pelajaran IPS relatif rendah, seperti terlihat pada Tabel berikut.

Karateristik mata pelajaran IPS SMP/MTs antara lain sebagai berikut: (1) Ilmu Pengetahuan Sosial merupakan gabungan dari unsur-unsur geografi, sejarah, ekonomi, hukum dan politik, kewarganegaraan, sosiologi, bahkan juga bidang humaniora, pendidikan dan agama; (2) Standar Kompetensi dan Kompetensi Dasar IPS berasal dari struktur keilmuan geografi, sejarah, ekonomi, dan sosiologi, yang dikemas sedemikian rupa sehingga menjadi pokok bahasan atau topik (tema) tertentu; (3) Standar Kompetensi dan Kompetensi Dasar IPS juga menyangkut berbagai masalah sosial yang dirumuskan dengan pendekatan interdisipliner dan multidisipliner; (4) Standar Kompetensi dan Kompetensi Dasar dapat menyangkut peristiwa dan perubahan kehidupan masyarakat dengan prinsip sebab akibat, kewilayahan, adaptasi dan pengelolaan lingkungan, struktur, proses dan masalah sosial serta upaya-upaya perjuangan hidup agar survive seperti pemenuhan kebutuhan, kekuasaan, keadilan dan jaminan keamanan.

Standar Kompetensi dan Kompetensi Dasar IPS menggunakan tiga dimensi dalam mengkaji dan memahami fenomena sosial serta kehidupan manusia secara keseluruhan. Secara umum strategi mempunyai arti suatu garis-garis haluan untuk bertindak atau melakukan sesuatu dalam usaha dalam mencapai sasaran yang telah ditentukan. Dapat dikatakan bahwa strategi pembelajaran merupakan pola-pola umum kegiatan guru dan siswa dalam bentuk kegiatan belajar mengajar untuk mencapai tujuan yang telah ditetapkan sebelumnya. Strategi digunakan untuk memperoleh kesuksesan atau keberhasilan dalam mencapai tujuan. Dalam dunia pendidikan, strategi diartikan sebagai $a$ plan, method, or series of activities designed to achieves a particular educational goal hal ini dikemukakan oleh J.R. David (dalam Sanjaya, 2008:126).

Strategi Instruksional ini merupakan proses memilih dan menyusun kegiatan pembelajaran dalam suatu unit pembelajaran seperti urutan, sifat materi,ruang lingkup materi,metode dan media yang paling sesuai untuk mencapai kompetensi pembelajaran (Warsita,2008:24) . Miarso (2004:530) menjelaskan pengertian strategi pembelajaran adalah pendekatan menyeluruh pembelajaran dalam situasi sistem pembelajaran, yang berupa pedoman umum dan kerangka kegiatan untuk mencapai tujuan umum pembelajaran, yang dijabarkan dari pandangan falsafah dan atau teori pembelajaran tertentu.

Kemp (dalam Sanjaya, 2010;126) menjelaskan strategi pembelajaran suatu kegiatan pembelajaran yang harus dikerjakan guru dan siswa agar tujuan pembelajaran dapat dicapai secara efektif dan efesien. Senada dengan pendapat Dick \& Carey (2005) juga menyebutkan bahwa strategi pembelajaran itu adalah suatu set materi dan prosedur pembelajaran yang diigunakan secara bersamasama untuk menimbulkan hasil belajar siswa.Sedangkan Gerlach dan Ely (dalam Warsita, 2008:268) menyebutkan sebagai suatu pendekatan guru terhadap penggunaan informasi, mulai dari pemilihan sumber belajar sampai pada menetapkan peranan peserta didik dalam pembelajaran. Pembelajaran berbasis masalah merupakan cerminan pandangan John Dewey sebagai tokoh penyusunan teori pendidikan yang menyatakan tidak ada hal di dalam filosof pendidikan progresif yang lebih bermakna daripada penekanannya terhadap 
makna penting partisipasi peserta didik di dalam penyusunan terhadap makna penting partisipasi peserta di dalam penyusunan tujuan yang mengarahkan kegiatannya di dalam proses pembelajaran. Dewey (dalam Arends, 2008:46) mendeskripsikan tentang pendidikan dengan sekolah sebagai cerminan masyarakat yang lebih besar dan kelas akan menjadi laboratorium untuk penyelidikan dan pengatasan masalah kehidupan nyata. Pedagogi Dewey mendorong guru untuk siswa di berbagai proyek berorientasi masalah dan membantu mereka menyelidiki berbagai masalah sosial dan intelektual.

Lebih lanjut Sanjaya (2010: 179) menyatakan bahwa strategi pembelajaran ekspositori adalah strategi pembelajaran yang menekankan kepada proses penyampaian materi secara verbal dari seorang guru kepada sekelompok siswa dengan maksud agar siswa dapat menguasai materi pelajaran secara optimal. Terdapat beberapa karakteristik strategi pembelajaran ekspositori. Pertama, strategi ekspositori dilakukan dengan cara menyampaikan materi pelajaran secara verbal, artinya bertutur secara lisan merupakan alat utama dalam melakukan strategi ini, oleh karena itu sering orang mengidentikannya dengan ceramah. Kedua, biasanya materi pelajaran yang disampaikan adalah materi yang pelajaran yang sudah jadi, seperti data atau fakta, konsep-konsep tertentu yang harus dihafal sehingga tidak menuntut siswa untuk berfikir ulang. Ketiga, tujuan utama pembelajaran adalah penguasaan materi pelajaran itu sendiri. Artinya, setelah proses pembelajaran berakhir siswa diharapkan siswa diharapkan dapat memahaminya dengan benar dan mengungkapkan kembali materi yang telah diuraikan.

Teiller (dalam DePorter \& Hernacki, 2011:134) mengatakan bahwa kemampuan berpikir adalah cara yang konsisten yang dilakukan individu dalam mencari informasi, cara mengingat serta memikirkan cara penyelesaian suatu persoalan. Ahmadi (2005:31) mengemukakan berpikir adalah daya yang dapat meletakkan hubungan antra pengetahuan kita. Berpikir merupakan proses dialektid artinya selama berpikir kita berada dalam keadaan Tanya jawab untuk menghubungkan pengetahuan yang kita miliki. Sejalan dengan Frankel (dalam Patmonodewo, 2008:38) mendefenisikan berpikir sebagai pembentukan ide-ide, reorganisasi dan pengalaman-pengalaman seorang dan pengorganisasian informasi-informasi ke dalam bentuk yang khas. Dari pendapat di atas di ambil suatu simpulan bahwa komponen dasar yang perlu dalam berpikir adalah persepsi, mengingat, membandingkan, mengkategorikan dan penyimpulan.

Kemampuan berpikir abstrak merupakan salah satu jenis kemampuan yang merupakan atribut inteligensi. Menurut Termen seperti yang dikutip oleh Winkel \& Lewis R. Aiken (2007), inteligensi merupakan kemampuan berpikir abstrak. Kemampuan berpikir abstrak ini adalah suatu aspek yang penting dari inteligensi, tetapi bukan satusatunya. Gregore (dalam Ide, 2009:106) menjelaskan orang atau individu yang memiliki kemampuan berpikir abstrak cenderung memiliki pola pikir logis, rasional dan intelektual. Selain itu cenderung juga menggunakan konsep dalam menyelesaikan suatu masalah dan selau menganalisis suatu informasi yang diterimanya.

Sedangkan menurut Teiller (dalam DePorter \& Hernacki, 2011:134) seseorang yang memiliki kemampuan berpikir sekuensial abstrak berkarakter analitis, suka berdebat, daya cipta tinggi, akedemis, sistematis, penuh persaan, logis, intelektual, pembaca, berpikir mendalam, penilai, menggunakan nalar, korektif. Menurut Gregore (dalam Ide, 2009) orang atau individu yang mempunyai kemampuan berpikir sekuensial kongkret dalam aktivitas berpikirnya berdasarkan pada realitas yang mereka serap melalui indera fisik seperti indera penglihatan, pendengaran, persentuhan, pengucapan, pengecapan, dan penciuman. Teiller (dalam DePorter \& Hernacki, 2011:134) menyatakan bahwa sekuensial kongkret dalam menerima informasi cenderung membutuhkan penjelasan dan tujuan yang menyeluruh dari suatu permasalahan. Mereka memperhatikan dan mengingat realitas dengan asosiasi visual secara teliti dan detail.Pemikir sekuensial kongkret mempunyai masalah untuk mengingat interuksi secara verbal kecuali jika ditulis, dan seringkali minta bantuan orang untuk mengulanginya. Mereka sangat baik dalam membuat catatan dari informasi yang diterimanya.

Penelitian ini bertujuan untuk memperoleh gambaran tentang pengaruh penggunaan strategi pembelajaran dengan menggunakan media internet dan interaksi sosial terhadap hasil belajar siswa pada mata pelajaran IPS, sedangkan secara khusus penelitian ini bertujuan untuk: (1) mengetahui 
hasil belajar IPS siswa yang diajar dengan strategi pembelajaran berbasis masalah menggunakan media internet lebih tinggi daripada siswa yang diajar dengan strategi pembelajaran ekspositori menggunakan media internet; (2) mengetahui hasil belajar IPS siswa yang memiliki memiliki kemampuan berpikir sekuensial abstrak lebih tinggi dari pada siswa yang memiliki kemampuan sekuensial konkrit; (3) mengetahui interaksi antara strategi pembelajaran menggunakan media internet dengan kemampuan berpikir sekuensial terhadap hasil belajar IPS.

\section{METODE PENELITIAN}

Penelitian ini dilaksanakan di SMP Negeri 4 Sei Suka, Jalan Datuk Panglima Tenggang Desa Kuala Indah Kabupaten Batu Bara pada semester ganjil . Populasi penelitian ini adalah seluruh siswa kelas VIII, yang terdiri dari 5 kelas yaitu kelas VIII ${ }^{1}$, VIII ${ }^{2}$, VIII ${ }^{3}$, VIII ${ }^{4}$ dan VIII ${ }^{5}$ dengan jumlah keseluruhan siswa adalah 165 orang. Teknik pengambilan sampel dalam penelitian ini adalah teknik sampel kelompok secara acak (cluster random sampling) yakni 4 kelas di pilih 2 kelas sebagai sampel yang dikenakan perlakuan melalui pemilihan secara acak.

Penelitian ini menggunakan metode eksperimen dengan rancangan quasi eksperimen disain faktorial $2 \times 2$. Dengan melakukan eksperimen didalam kelas yang sudah tersedia sebagaimana adanya tanpa melakukan perubahan situasi kelas dan jadwal pembelajaran, sedangkan karekteristik siswa yang dikontrol adalah kemampuan berpikir, sedangkan perlakuan yang dilaksanakan adalah strategi pembelajaran menggunakan media internet pada mata pelajaran IPS.

Untuk menguji kebenaran hipotesis yang diajukan dalam penelitian ini, maka tekhnik analisis data yang digunakan adalah analisis varians (ANAVA). Maka tehnik ini dengan maksud agar hasil tes akhir yang dicapai oleh subyek penelitian benar-benar karena pengaurh dari perlakuan yang diberikan selama penelitian. Taraf signifikan yang digunakan dalam penelitian ini adalah $\alpha 0,05$. Hasil pengujian menunjukan terdapatnya interaksi antara strategi pembelajaran menggunakan internet dengan kemampuan berpikir siswa sehingga perlu dilakukan uji lanjut. Karena tiap sel berbeda maka uji lanjut dilakukan dengan uji Scheffe.

Untuk menggunakan ANAVA dua jalur perlu di penuhi beberapa syarat yaitu: (1) data yang digunakan harus birdistribusi normal, dan (2) data harus memiliki populasi homogen. Untuk menguji normalitas data digunakan uji Lilifors dan untuk menguji homogenitas varians digunakan uji F (Fisher) dan uji Bartlet.

\section{HASIL DAN PEMBAHASAN Hasil}

Data-data hasil temuan penelitian dikelompok berdasarkan interaksi antara strategi pembelajaran menggunakan media internet dengan kemampuan berpikir sekuensial siswa. Perbandingan kelompok data-data hasil belajar siswa berdasarkan temuan penelitian, secara ringkas dirangkum pada Tabel 1.

Tabel 1. Perbandingan Data Hasil Belajar IPS Siswa Berdasarkan Strategi Pembelajaran Menggunakan Media Internet dan Kemampuan Berpikir Sekuensial Siswa

\begin{tabular}{|c|c|c|c|c|c|c|c|c|c|}
\hline 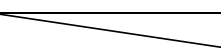 & \multicolumn{6}{|c|}{ Strategi Pembelajaran } & \multirow{2}{*}{\multicolumn{3}{|c|}{ Total }} \\
\hline $\begin{array}{l}\text { Kemampuan } \\
\text { Berpikir } \\
\text { Sekuensial }\end{array}$ & \multicolumn{3}{|c|}{$\begin{array}{l}\text { Berbasis Masalah } \\
\text { Menggunakan Media } \\
\text { Internet (A1) }\end{array}$} & \multicolumn{3}{|c|}{$\begin{array}{c}\text { Ekspositori } \\
\text { Menggunakan Media } \\
\text { Internet (A2) }\end{array}$} & & & \\
\hline \multirow{3}{*}{$\begin{array}{c}\text { Abstrak } \\
\text { (B1) }\end{array}$} & $\mathrm{n}_{1}$ & $=$ & 21 & $\mathrm{n}_{2}$ & $=$ & 19 & $\mathrm{nB}_{1}$ & $=$ & 40 \\
\hline & $\overline{\mathrm{x}}_{1}$ & $=$ & 85,57 & $\overline{\mathrm{X}}_{2}$ & $=$ & 74,42 & $\overline{\mathrm{X}} \mathrm{B}_{1}$ & $=$ & 80,28 \\
\hline & $\mathrm{s}_{1}$ & $=$ & 6,17 & $\mathrm{~S}_{2}$ & $=$ & 6,87 & $\mathrm{~S}_{\mathrm{B} 1}$ & $=$ & 8,55 \\
\hline \multirow{3}{*}{$\begin{array}{l}\text { Konkret } \\
\text { (B2) }\end{array}$} & $\mathrm{n}_{3}$ & $=$ & 14 & $\mathrm{n}_{4}$ & $=$ & 16 & $\mathrm{nB}_{2}$ & $=$ & 30 \\
\hline & $\overline{\mathrm{X}}_{3}$ & $=$ & 75,00 & $\overline{\mathrm{X}}_{4}$ & $=$ & 77,13 & $\overline{\mathrm{X}} \mathrm{B}_{2}$ & $=$ & 76,13 \\
\hline & $\mathrm{S}_{3}$ & $=$ & 5,48 & $\mathrm{~S}_{4}$ & $=$ & 7,84 & $\mathrm{~S}_{\mathrm{B} 2}$ & $=$ & 6,81 \\
\hline \multirow{3}{*}{ Total } & $\mathrm{nA}_{1}$ & $=$ & 35 & $\mathrm{nA}_{2}$ & $=$ & 35 & $\mathrm{n}_{\mathrm{t}}$ & $=$ & 70 \\
\hline & $\overline{\mathrm{X}} \mathrm{A}_{1}$ & $=$ & 81,34 & $\overline{\mathrm{X}} \mathrm{A}_{2}$ & $=$ & 75,66 & $\bar{x}_{t}$ & $=$ & 78,50 \\
\hline & $\mathrm{S}_{\mathrm{A} 1}$ & $=$ & 7,84 & $\mathrm{~S}_{\mathrm{A} 2}$ & $=$ & 7,35 & $\mathrm{~S}_{\mathrm{t}}$ & $=$ & 8,07 \\
\hline
\end{tabular}


Pengujian hipotesis dilakukan menggunakan teknik analisis varians (anava) dua jalur dengan desain faktorial $2 \times 2$.

Tabel 2. Rangkuman Hasil Pengujian Analisis Varians Dua Jalur

\begin{tabular}{|l|c|c|r|r|c|}
\hline \multicolumn{1}{|c|}{ Sumber Variasi } & dk & \multicolumn{1}{c|}{$\mathrm{JK}$} & $\mathrm{RK}=\mathrm{JK} / \mathrm{dk}$ & \multicolumn{1}{c|}{$\mathrm{Fh}$} & $\mathrm{Ft} \alpha=0,05$ \\
\hline Antar Kolom (A) & 1 & 565,729 & 565,729 & 12,772 & 3,99 \\
Antar Baris (B) & 1 & 294,058 & 294,058 & 6,639 & 3,99 \\
Interaksi (AB) & 1 & 708,189 & 708,189 & 15,988 & 3,99 \\
Dalam & 66 & 2923,524 & 44,296 & & \\
\hline Total Direduksi & 69 & 4491,50 & - & & \\
\hline
\end{tabular}

Perbedaan Hasil Belajar Siswa yang Diajar dengan Strategi Pembelajaran Berbasis Masalah Menggunakan Media Internet (A1) dan yang Diajar dengan Strategi Pembelajaran Ekspositori Menggunakan Media Internet (A2) Adapun hipotesis statistik, yang diuji adalah:

$$
\begin{aligned}
& \mathrm{H}_{\mathrm{o}}: \mu \mathrm{A}_{1}=\mu \mathrm{A}_{2} \\
& \mathrm{H}_{\mathrm{a}}: \mu \mathrm{A}_{1}>\mu \mathrm{A}_{2}
\end{aligned}
$$

Berdasarkan hasil penelitian diperoleh rata-rata hasil belajar IPS kelompok siswa yang diajar dengan strategi pembelajaran berbasis masalah menggunakan media internet sebesar 81,34 dan hasil belajar IPS kelompok siswa yang diajar dengan strategi pembelajaran eskpositori menggunakan media internet diperoleh rata-rata sebesar 75,66.

Hasil analisis pada Tabel 2, untuk hipotesis pertama (antar kolom) diperoleh nilai $F_{\text {hitung }}$ sebesar 12,772. Pada taraf signifikansi $\alpha$ $=0,05$ diperoleh $F_{0,05}(1 ; 66)=3,99$. Karena nilai $\mathrm{F}_{\text {hitung }}>\mathrm{F}_{\text {tabel }}$ yaitu $12,772>3,99$ maka untuk uji hipotesis pertama terima $\mathrm{H}_{a}$ sehingga disimpulkan hasil belajar IPS siswa yang diajar dengan strategi pembelajaran berbasis masalah menggunakan media internet lebih tinggi dari pada hasil belajar siswa yang diajar dengan strategi pembelajaran ekspositori menggunakan media internet.

Perbedaan Hasil Belajar Siswa yang Memiliki Kemampuan Berpikir Sekuensial Abstrak dengan Siswa yang Memiliki Kemampuan Berpikir Sekuensial Konkret adalah: Adapun hipotesis statistik, yang diuji

$$
\begin{aligned}
& \mathrm{H}_{\mathrm{o}}: \mu \mathrm{B}_{1}=\mu \mathrm{B}_{2} \\
& \mathrm{H}_{\mathrm{a}}: \mu \mathrm{B}_{1}>\mu \mathrm{B}_{2}
\end{aligned}
$$

Berdasarkan hasil temuan penelitian diperoleh rata-rata hasil belajar IPS kelompok siswa yang memiliki kemampuan berpikir sekuensial abstrak sebesar 80,28 dan kelompok siswa yang memiliki kemampuan berpikir sekuensial konkret diperoleh rata-rata hasil belajar sebesar 76,13.

Hasil analisis pada Tabel 2, untuk hipotesis kedua (antar baris) diperoleh nilai $F_{\text {hitung }}>F_{\text {tabel }}$ yaitu 6,639 > 3,99 maka terima $\mathrm{H}_{\mathrm{a}}$ sehingga disimpulkan bahwa hasil belajar IPS siswa yang memiliki kemampuan berpikir sekuensial abstrak lebih tinggi daripada hasil belajar IPS siswa yang memiliki kemampuan berpikir sekuensial konkret

Interaksi Antara Strategi Pembelajaran Menggunakan Media Internet dan Kemampuan Berpikir Sekuensial Siswa Terhadap Hasil Belajar IPS

Adapun hipotesis statistik, yang diuji adalah:

$$
\begin{aligned}
& \mathrm{H}_{\mathrm{o}}: \mu \mathrm{A}><\mu \mathrm{B}=0 \\
& \mathrm{H}_{\mathrm{a}}: \mu \mathrm{A}><\mu \mathrm{B} \neq 0
\end{aligned}
$$

Berdasarkan hasil temuan penelitian diperoleh hasil belajar IPS kelompok siswa yang diajar strategi pembelajaran berbasis masalah menggunakan media internet dan memiliki kemampuan berpikir sekuensial abstrak rata-rata sebesar 85,57; kelompok siswa yang diajar strategi pembelajaran berbasis masalah menggunakan media internet dan memiliki kemampuan berpikir sekuensial konkret diperoleh rata-rata sebesar 75,00; kelompok siswa yang diajar strategi pembelajaran ekspositori menggunakan media internet dan memiliki kemampuan berpikir sekuensial abstrak diperoleh rata-rata nilai sebesar 74,42; sementara kelompok siswa yang diajar strategi pembelajaran ekspositori menggunakan media internet dan memiliki kemampuan berpikir sekuensial konkret diperoleh rata-rata nilai sebesar 77,13. Selanjutnya berdasarkan hasil analisis varians pada Tabel 4.16, diperoleh nilai $F_{\text {hitung }}>F_{\text {tabel }}$ yaitu 15,988>3,99 sehingga terima $\mathrm{H}_{\mathrm{a}}$ dan disimpulkan terdapat interaksi antara strategi pembelajaran menggunakan media internet 
dengan kemampuan berpikir sekuensial dalam mempengaruhi hasil belajar IPS siswa.

Hasil pengujian yang ketiga dinyatakan terdapat interaksi antara strategi pembelajaran menggunakan media internet dengan kemampuan berpikir sekuensial terhadap hasil belajar IPS siswa. Karenanya, perlu dilakukan pengujian lanjutan untuk mengetahui rata-rata nilai kelompok mana yang memberi pengaruh lebih baik atau lebih tinggi terhadap hasil belajar IPS siswa. Uji lanjut dilakukan dengan uji Scheffe.

Tabel 3. Rangkuman Hasil Uji Scheffe

\begin{tabular}{|c|c|c|c|}
\hline No. & Perbandingan Rata-rata Nilai Kelompok & $\mathrm{F}_{\text {hitung }}$ & $\mathrm{F}_{\text {tabel }} \mathrm{F}_{0,05 ; 3 ; 76}$ \\
\hline 1 & $\mathrm{~A}_{1} \mathrm{~B}_{1}$ dengan $\mathrm{A}_{1} \mathrm{~B}_{2}$ & 21,187 & 8,25 \\
2 & $\mathrm{~A}_{1} \mathrm{~B}_{1}$ dengan $\mathrm{A}_{2} \mathrm{~B}_{1}$ & 27,996 & 8,25 \\
3 & $\mathrm{~A}_{1} \mathrm{~B}_{1}$ dengan $\mathrm{A}_{2} \mathrm{~B}_{2}$ & 14,604 & 8,25 \\
4 & $\mathrm{~A}_{1} \mathrm{~B}_{2}$ dengan $\mathrm{A}_{2} \mathrm{~B}_{1}$ & 0,061 & 8,25 \\
5 & $\mathrm{~A}_{1} \mathrm{~B}_{2}$ dengan $\mathrm{A}_{2} \mathrm{~B}_{2}$ & 0,765 & 8,25 \\
6 & $\mathrm{~A}_{2} \mathrm{~B}_{1}$ dengan $\mathrm{A}_{2} \mathrm{~B}_{2}$ & 1,440 & 8,25 \\
\hline
\end{tabular}

Tabel 3, menunjukkan:

a. Hasil uji Scheffe untuk perbedaan nilai antara A1B1 dengan A1B2 diperoleh $F_{\text {hitung }}$ $>\mathrm{F}_{\text {tabel }}$ yaitu $21,187>8,25$ sehingga disimpulkan ada perbedaan yang signifikan antara hasil belajar kelompok siswa yang memiliki kemampuan berpikir sekuensial abstrak diajar dengan strategi pembelajaran berbasis masalah menggunakan media internet (A1B1) dibandingkan kelompok siswa yang memiliki kemampuan berpikir sekuensial konkret diajar dengan strategi pembelajaran berbasis masalah menggunakan media internet (A1B2). Berdasarkan rata-rata nilai disimpulkan bahwa kelompok siswa yang memiliki kemampuan berpikir sekuensial abstrak diajar dengan strategi pembelajaran berbasis masalah menggunakan media internet $(85,57)$ memperoleh hasil belajar yang lebih tinggi dibandingkan kelompok siswa yang memiliki kemampuan berpikir sekuensial konkret diajar dengan strategi pembelajaran berbasis masalah menggunakan media internet $(75,0)$.

b. Hasil uji Scheffe untuk perbedaan nilai antara A1B1 dengan A2B1 diperoleh $F_{\text {hitung }}$ $>\mathrm{F}_{\text {tabel }}$ yaitu 27,996>8,25 sehingga disimpulkan ada perbedaan yang signifikan antara hasil belajar kelompok siswa yang memiliki kemampuan berpikir sekuensial abstrak diajar dengan strategi pembelajaran berbasis masalah menggunakan media internet (A1B1) dibandingkan kelompok siswa yang memiliki kemampuan berpikir sekuensial abstrak diajar dengan strategi pembelajaran ekspositori menggunakan media internet (A2B1). Berdasarkan ratarata nilai disimpulkan bahwa kelompok siswa yang memiliki kemampuan berpikir sekuensial abstrak diajar dengan strategi pembelajaran berbasis masalah menggunakan media internet $(85,57)$ memperoleh hasil belajar yang lebih tinggi dibandingkan kelompok siswa yang memiliki kemampuan berpikir sekuensial abstrak diajar dengan strategi pembelajaran ekspositori menggunakan media internet $(74,42)$

c. Hasil uji Scheffe untuk perbedaan nilai antara A1B1 dengan A2B2 diperoleh $F_{\text {hitung }}$ $>\mathrm{F}_{\text {tabel }}$ yaitu $16,287>8,25$ sehingga disimpulkan ada perbedaan yang signifikan antara hasil belajar kelompok siswa yang memiliki kemampuan berpikir sekuensial abstrak diajar dengan strategi pembelajaran berbasis masalah menggunakan media internet (A1B1) dibandingkan kelompok siswa yang memiliki kemampuan berpikir sekuensial konkret diajar dengan strategi pembelajaran ekspositori menggunakan media internet (A2B2). Berdasarkan ratarata nilai disimpulkan bahwa kelompok siswa yang memiliki kemampuan berpikir sekuensial abstrak diajar dengan strategi pembelajaran berbasis masalah menggunakan media internet $(85,57)$ memperoleh hasil belajar yang lebih tinggi dibandingkan kelompok siswa yang memiliki kemampuan berpikir sekuensial konkret diajar dengan strategi pembelajaran ekspositori menggunakan media internet $(77,13)$.

d. Hasil uji Scheffe untuk perbedaan nilai antara A1B2 dengan A2B1 diperoleh $\mathrm{F}_{\text {hitung }}$ $<\mathrm{F}_{\text {tabel }}$ yaitu $0,061<8,25$ sehingga disimpulkan tidak ada perbedaan yang signifikan antara hasil belajar kelompok 
siswa yang memiliki kemampuan berpikir sekuensial konkret diajar dengan strategi pembelajaran berbasis masalah menggunakan media internet (A1B2) dibandingkan kelompok siswa yang memiliki kemampuan berpikir sekuensial abstrak diajar dengan strategi pembelajaran ekspositori menggunakan media internet (A2B1). Berdasarkan rata-rata nilai disimpulkan bahwa hasil belajar kelompok siswa yang memiliki kemampuan berpikir sekuensial konkret diajar dengan strategi pembelajaran berbasis masalah menggunakan media internet $(75,00)$ tidak lebih tinggi dibandingkan kelompok siswa yang memiliki kemampuan berpikir sekuensial abstrak diajar dengan strategi pembelajaran ekspositori menggunakan media internet $(74,42)$ atau selisih rata-rata hanya sebsar 0,58 .

e. Hasil uji Scheffe untuk perbedaan nilai antara A1B2 dengan A2B2 diperoleh $\mathrm{F}_{\text {hitung }}$ $<\mathrm{F}_{\text {tabel }}$ yaitu $0,765<8,25$ sehingga disimpulkan tidak ada perbedaan yang signifikan antara hasil belajar kelompok siswa yang memiliki kemampuan berpikir sekuensial konkret diajar dengan strategi pembelajaran berbasis masalah menggunakan media internet (A1B2) dibandingkan kelompok siswa yang memiliki kemampuan berpikir sekuensial konkret diajar dengan strategi pembelajaran ekspositori menggunakan media internet (A2B2). Berdasarkan rata-rata nilai disimpulkan bahwa hasil belajar kelompok siswa yang memiliki kemampuan berpikir sekuensial konkret diajar dengan strategi pembelajaran berbasis masalah menggunakan media internet $(75,0)$ tidak lebih tinggi atau lebih rendah dibandingkan kelompok siswa yang memiliki kemampuan berpikir sekuensial konkret diajar dengan strategi pembelajaran ekspositori menggunakan media internet $(77,13)$ atau selisih rata-rata nilai sebesar 2,13.

f. Hasil uji Scheffe untuk perbedaan nilai antara A2B1 dengan A2B2 diperoleh $\mathrm{F}_{\text {hitung }}$ $<\mathrm{F}_{\text {tabel }}$ yaitu $1,440<8,25$ sehingga disimpulkan tidak ada perbedaan yang signifikan antara hasil belajar kelompok siswa yang memiliki kemampuan berpikir sekuensial abstrak diajar dengan strategi pembelajaran ekspositori menggunakan media internet (A2B1) dibandingkan kelompok siswa yang memiliki kemampuan berpikir sekuensial konkret diajar dengan strategi pembelajaran ekspositori menggunakan media internet (A2B2). Berdasarkan rata-rata nilai disimpulkan bahwa hasil belajar kelompok siswa yang memiliki kemampuan berpikir sekuensial abstrak diajar dengan strategi pembelajaran ekspositori menggunakan media internet $(74,42)$ tidak lebih tinggi atau lebih rendah dibandingkan kelompok siswa yang memiliki kemampuan berpikir sekuensial konkret diajar dengan strategi pembelajaran ekspositori menggunakan media internet $(77,13)$ atau selisih rata-rata 2,71 .

Sesuai dengan kerangka berpikir, maka menunjukkan ada interaksi antara strategi pembelajaaran menggunakan media internet dan kemampuan berpikir sekuensial terhadap hasil belajar IPS siswa yaitu hasil belajar IPS kelompok siswa yang memiliki kemampuan berpikir sekuensial abstrak diajar dengan strategi pembelajaran berbasis masalah menggunakan media internet secara signifikan lebih tinggi dari kelompok siswa yang memiliki kemampuan berpikir sekuensial abstrak diajar strategi pembelajaran ekspositori menggunakan media internet $(85,57>74,42)$ pada butir (b) uji Scheffe, sementara untuk kelompok siswa yang memiliki kemampuan berpikir sekuensial konkret diajar strategi pembelajaran berbasis masalah menggunakan media internet secara signifikan lebih rendah atau tidak lebih tinggi dari kelompok siswa yang memiliki kemampuan berpikir sekuensial konkret diajar dengan strategi pembelajaran ekspositori menggunakan media internet $(75,00<77,13)$ pada butir (e) uji Scheffe.

Lebih jelasnya adanya interaksi antara strategi pembelajaran menggunakan media internet dan kemampuan berpikir sekuensial siswa terhadap hasil belajar IPS siswa, dapat divisualisasikan pada Gambar 1. 


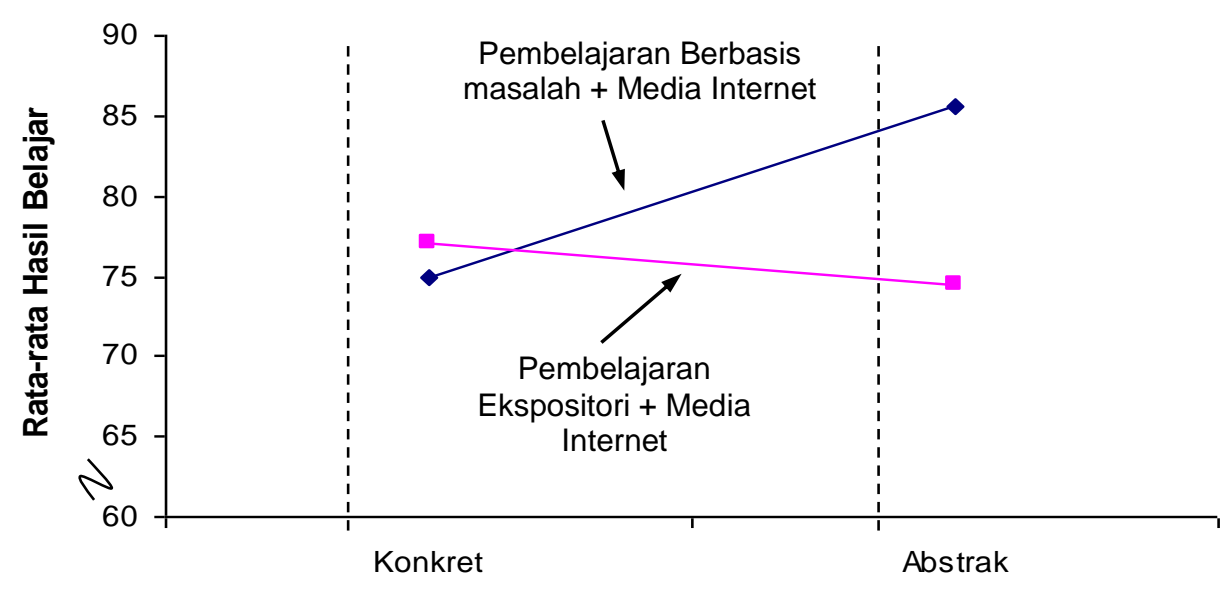

Kemampuan Berpikir Sekuensial

Gambar 1. Pola Interaksi Antara Strategi Pembelajaran Menggunakan Media Internet dan Kemampuan Berpikir Sekuensial Terhadap Hasil Belajar IPS Siswa

\section{Pembahasan}

Kesimpulan di atas juga didukung penelitian yang dilakukan Linda (2009) yang menyimpulkan bahwa rata-rata hasil belajar biologi siswa yang diajar dengan strategi pembelajaran berbasis masalah lebih tinggi dibandingkan dengan siswa yang diajar dengan strategi pembelajaran konvesional.

Melalui pemecahan masalah dapat memperlihatkan kepada siswa bahwa setiap mata pelajaran khususnya mata pelajaran IPS pada dasarnya merupakan cara berpikir dan sesuatu yang harus dimengerti oleh siswa, bukan hanya sekedar belajar dari guru atau dari buku-buku saja. Oleh karena itu, pemecahan masalah dapat mengembangkan kemampuan siswa untuk berpikir kritis mencari informasiinformasi yang bersumber dari internet yang diperlukan dalam menyelesaikan masalah dan mengembangkan kemampuan mereka untuk menyesuaikan dengan pengetahuan baru. Guru bertugas membantu siswa melalui upaya mendorong siswa mencari informasi seluasluasnya kemudian dapat memberikan umpan balik dari diskusi yang mereka laksanakan. Dengan demikian, siswa memiliki kesempatan untuk mengaplikasikan pengetahuan yang mereka miliki dalam dunia nyata sebab siswa terlibat secara aktif dalam mengkontruk sendiri konsep pengetahuan dalam mata pelajaran IPS melalui berbagai sumber yang berasal dari internet.

Sementara itu strategi pembelajaran ekspositori menggunakan media internet merupakan pembelajaran yang berpusat pada guru, siswa kurang diberdayakan dan komunikasi yang terjadi umumnya bersifat satu arah. Siswa tidak mencari sendiri sumber dan hanya diberi petunjuk oleh guru situs-situs atau alamat-alamat internet yang harus dicari siswa dalam mengerjakan tugas yang diberikan oleh guru. Dalam proses pelekasanaan strategi pembelajaran ekspositori menggunakan media internet siswa hanya dapat menyelesaikan masalah sesuai dengan cara yang ditunjukkan guru, hingga membuat siswa bersifat menunggu penjelasan atau intruksi dari guru. Pengetahuan siswa juga terbatas pada informasi yang berasal dari situs-situs yang diberikan guru, mereka tidak diberikan kesempatan untuk menemukan sendiri suatu konsep, pengetahuan atau keterampilan. Akibatnya hasil belajar yang diperoleh siswa dengan menggunakan strategi ini umumnya tidak bertahan lama dalam struktur kognitif siswa.

Berdasarkan hasil dan temuan-temuan penelitian yang diperoleh, maka dapat diindikasikan bahwa strategi pembelajaran berbasis masalah menggunakan media internet memberikan pengaruh yang lebih baik dalam meningkatkan hasil belajar IPS siswa dibandingkan strategi pembelajaran ekspositori menggunakan media internet. Dengan demikian, berdasarkan hasil penelitian yang telah dilakukan diperoleh bahwa hasil belajar IPS siswa yang diajar dengan strategi pembelajaran berbasis masalah menggunakan media internet lebih tinggi dibandingkan hasil belajar IPS siswa yang diajar dengan strategi pembelajaran ekspositori menggunakan media internet.

Kesimpulan tersebut di atas juga didukung oleh penelitian Rahmah El Yunusiah (2011) yang menyimpulkan bahwa terdapat 
perbedaan hasil belajar kewirausahaan antara siswa yang memiliki kemampuan berpikir sekuensial abstrak dengan siswa yang memiliki kemampuan berpikir sekuensial kongkret. Siswa yang memiliki kemampuan berpikir sekuensial abstrak memperoleh hasil belajar yang lebih tinggi dari pada siswa yang memiliki kemampuan berpikir sekuensial kongkret.

Pada pembelajaran IPS diperlukan suatu model pemikiran sebuah konsep yang logis, rasional, kritis, cermat dan efektif serta efisien. Sesuai dengan hal ini kemampuan siswa adalah merupakan indikator yang perlu diperhatikan agar hasil belajarnya lebih baik. Hal tersebut dapat menjadi pertimbangan pada penentuan metode pembelajaran yang digunakan. Kemampuan berpikir sekuensial abstrak merupakan suatu model berpikir yang menggunakan konsep dalam menganalisis suatu informasi bersifat logis, rasional dan intelektual. Siswa yang memiliki kemampuan berpikir seperti ini lebih suka bekerja sendiri dan selalu ingin mengetahui sebab-sebab suatu persoalan.

Sedangkan siswa yang memiliki kemampuan berpikir sekuensial konkret cenderung pola pikirnya atas dasar realitas. Mereka menggunakan indera fisik untuk membuktikan kebenaran suatu informasi, memiliki pola pikir teratur dan spesifik, suka bekerja dengan menggunakan bantuan dan arahan dari orang lain. Dengan kata lain siswa yang memiliki kemampuan sekuensial konkret ini cenderung suka bekerja dalam kelompok. Mereka selalu berusaha mendapatkan kesempurnaan dari pekerjaan mereka tahap demi tahap.

Berdasarkan hasil temuan penelitian yang ada, maka memberi indikasi bahwa kemampuan berpikir sekuensial siswa berpengaruh terhadap hasil belajar IPS yang dicapai siswa. Dengan demikian, dari hasil penelitian yang telah dilakukan diperoleh bahwa hasil belajar IPS siswa yang memiliki kemampuan berpikir sekuensial abstrak lebih tinggi dibandingkan kelompok siswa yang memiliki kemampuan berpikir sekuensial konkret.

Kesimpulan tersebut di atas juga sekaligus mendukung penelitian Penelitian Meri Rosmalinda Panjaitan (2011) yang menyimpulkan bahwa terdapat pengaruh interaksi strategi pembelajaran dan kemampuan berpikir terhadap hasil belajar Bahasa Inggris siswa.
Strategi pembelajaran merupakan metode dan prosedur yang menitikberatkan pada kegiatan siswa dalam proses pembelajaran untuk mencapai tujuan tertentu. Strategi pembelajaran merupakan faktor eksternal yang dapat mendukung proses internal dalam belajar, seperti mengalihkan perhatian, memberi motivasi, memberi bimbingan, menilai hasil karya dan memberikan umpan balik. Sedangkan kemampuan berpikir adalah salah satu faktor internal yang dapat mendorong keberhasilannya dalam menyelesaikan suatu persoalan. Keterkaitan antara pembelajaran dan kemampuan berpikir siswa dalam situasi pembelajaran merupakan hal yang sangat perlu diperhatikan. Sebagaimana yang dikemukakan para ahli di bidang pendidikan bahwa untuk meningkatkan hasil pembelajaran harus disesuaikan dengan karakteristik siswa.

Siswa yang memiliki kemampuan berpikir sekuensial abstrak yang cenderung dalam berpikir menggunakan konsep, memiliki pola berpikir yang logis, rasional dan intelektual, lebih suka belajar sendiri, mampu melihat adanya informasi yang saling berhubungan dengan benar, dapat melakukan analisis dengan metode deduktif, serta dapat menarik kesimpulan untuk memberi jawaban atas permasalahan-permasalahan berdasarkan fakta, konsep dan teori-teori yang mendukung sehingga diduga akan lebih efektif di ajar dengan menggunakan strategi pembelajaran berbasis masalah menggunakan media internet untuk meningkatkan prestasi belajarnya. sebab startegi ini proses pembelajarannya sangat berpusat pada kemampuan siswa dalam menemukan jawaban dari suatu permasalahan dalam pelajaran dan menekankan pada langkahlangkah berpikir yang dimulai dari menyadari kesenjangan, merumuskan masalah, membuat hipotesis dan mengumpulkan data serta menarik kesimpulan untuk mencapai pada penyelesaian masalah.

Sebaliknya jika siswa memiliki kemampuan berpikir abstrak di ajar dengan strategi pembelajaran ekspositori menggunakan media internet diduga prestasinya akan lebih rendah, sebab metode ini didominasi oleh guru, sehingga siswa yang memiliki kemampuan berpikir abstrak untuk mengetahui sebab-sebab dari suatu persoalan dengan kemampuan yang ada pada dirinya tidak terealisasikan dengan baik, sehingga timbul rasa kejenuhan dalam belajar yang mengakibatkan prestasi belajarnya rendah. 
Sementara itu siswa yang memiliki kemampuan berpikir sekuensial konkrit, yaitu siswa yang memiliki pola pikir teratur dan spesifik, suka menyelesaikan suatu permasalahan secara tahap demi tahap dan memiliki prosedur lengkap yang diberikan oleh orang lain untuk menemukan suatu konsep baru dalam belajar bila diajar dengan menggunakan strategi pembelajaran berbasis masalah kurang meningkatkan hasil belajarnya. Sebab strategi ini lebih berpusat pada siswa, guru hanya sebagai pemotivator atau pembimbing. Dengan demikian siswa yang memiliki kemampauan berpikir sekuensial konkrit kurang mampu menyelesaikan persoalan-persoalan atau dengan kata lain kurang dapat menyelesaikan permasalahan dengan baik. Bagi siswa yang memiliki kemampuan berpikir sekuensial konkrit dalam proses pembelajaran, strategi pembelajaran ekspositori menggunakan media internet akan lebih efektif digunakan untuk meningkatkan prestasi belajarnya. sebab langkah-langkah yang digunakan dalam strategi pembelajaran ekspositori sesuai dengan karakteristik siswa yang memiliki kemampuan berpikir sekuensial konkrit yaitu memiliki pola pikir yang teratur, cenderung menyelesaikan permasalahan tahap demi tahap dan memerlukan prosedur yang lengkap serta memerlukan penjelasan dari orang lain.

Berdasarkan rata-rata hasil belajar yang diperoleh siswa memberi indikasi bahwa kelompok siswa yang memiliki kemampuan berpikir sekuensial abstrak akan memperoleh hasil belajar yang lebih baik jika diajar dengan strategi pembelajaran berbasis masalah menggunakan media internet dibandingkan strategi pembelajaran ekspositori menggunakan media internet. Sebaliknya kelompok siswa yang memiliki kemampuan berpikir sekuensial konkret akan memperoleh hasil belajar yang lebih baik jika diajar dengan strategi pembelajaran ekspositori menggunakan media internet dibandingkan strategi pembelajaran berbasis masalah menggunakan media internet. Dengan demikian, dari hasil temuan penelitian dan pengujian hipotesis terbukti bahwa ada pengaruh strategi pembelajaran menggunakan media internet dan kemampuan berpikir sekuensial terhadap hasil belajar IPS siswa baik secara terpisah maupun secara interaksi atau bersamaan.

\section{PENUTUP \\ Simpulan}

Hasil-hasil temuan penelitian dan analisis yang telah dilakukan, diperoleh beberapa simpulan, antara lain:

1. Hasil belajar IPS siswa yang diajar dengan strategi pembelajaran berbasis masalah menggunakan media internet lebih tinggi daripada hasil belajar siswa yang diajar dengan strategi pembelajaran ekspositori menggunakan media. Berdasarkan rata-rata nilai kedua kelompok, menunjukkan bahwa strategi pembelajaran berbasis masalah menggunakan media internet memberikan pengaruh lebih tinggi dibandingkan strategi pembelajaran ekspositori menggunakan media internet. Meskipun pengaruh ini tidaklah terlalu besar, namun keaktifan dan kemampuan siswa dalam memecahkan masalah yang diajar dengan strategi pembelajaran berbasis masalah menggunakan media internet lebih berkembang melalui tahap-tahap pembelajaran yang dilakukan dibandingkan siswa yang diajar strategi pembelajaran ekspositori menggunakan media internet yang proses pembelajarannya berpusat pada guru.

2. Hasil belajar IPS siswa yang memiliki kemampuan berpikir sekuensial lebih tinggi daripada hasil belajar IPS siswa yang memiliki kemampuan berpikir sekuensial konkret. Berdasarkan nilai rata-rata kedua kelompok menunjukkan bahwa rata-rata hasil belajar IPS kelompok siswa yang memiliki kemampuan berpikir sekuensial abstrak lebih tinggi dibandingkan kelompok siswa yang memiliki kemampuan berpikir sekuensial konkret. Hal ini memberi indikasi bahwa karakteristik yang dimiliki siswa dalam hal ini kemampuan berpikir sekuensial juga turut mempengaruhi hasil belajar yang dicapai siswa.

3. Terdapat interaksi antara strategi pembelajaran menggunakan media internet dengan kemampuan berpikir sekuensial dalam mempengaruhi hasil belajar IPS siswa. Berdasarkan nilai rata-rata yang diperoleh siswa memberi indikasi bahwa kelompok siswa yang memiliki kemampuan berpikir sekuensial abstrak lebih tepat jika diajar dengan strategi pembelajaran berbasis masalah menggunakan media internet. Sebaliknya kelompok siswa yang memiliki kemampuan berpikir sekuensial konkret lebih tepat jika diajar dengan 
strategi pembelajaran ekspositori menggunakan media internet.

\section{Saran}

Berdasarkan simpulan yang telah dikemukakan, maka sebagai tindak lanjut dari penelitian ini disarankan beberapa hal sebagai berikut:

1. Kepada guru IPS diharapkan untuk lebih kreatif dan inovatif dalam memilih maupun menentukan strategi pembelajaran yang akan digunakan dalam menyampaikan materi dan melibatkan siswa secara aktif dalam belajar dan disarankan kepada guru untuk dapat menggunakan strategi pembelajaran berbasis masalah dan menggunakan media internet dalam menyampaikan konsep-konsep IPS agar siswa lebih berperan aktif dalam proses pembelajaran dan terlatih untuk mampu memecahkan berbagai masalah sosial yang dihadapi siswa dalam lingkungan masyarakat serta menghapus mind set siswa bahwa pelajaran IPS adalah pelajaran teoritis, hafalan dan membosankan.

2. Agar penerapan strategi pembelajaran yang dilakukan guru berjalan dengan efektif dan efisien sebaiknya guru terlebih dahulu melakukan identifikasi terhadap karakteristik, kebutuhan maupun kemampuan berpikir sekuensial (abstrak atau konkret) yang dimiliki siswa dengan memberikan seperangkat tes kemampuan berpikir sekuensial kepada siswa. Peneliti menyarankan jika dalam satu kelas dari hasil tes yang diberikan mayoritas siswa memiliki kemampuan berpikir sekuensial abstrak maka sebaiknya guru menggunakan strategi pembelajaran berbasis masalah menggunakan media internet dan sebaliknya jika dalam satu kelas mayoritas siswa memiliki kemampuan berpikir sekuensial konkret sebaiknya guru menggunakan strategi pembelajaran eskpositori menggunakan media internt.

3. Sejalan dengan semakin majunya teknologi informasi dan komunikasi, diharapkan kepada pihak sekolah untuk lebih memperhatikan penyediaan fasilitas pembelajaran yang dapat membatu guru dalam menjalankan tugasnya dengan baik, terutama fasilitas komputer maupun wifi di sekolah sebagai alat dan media pembelajaran, dan disarankan kepada kepala sekolah untuk dapat mengikutsertakan para guru dalam pelatihan-pelatihan komputer agar guru dapat mengoperasikan program-program komputer dengan baik dalam menunjang efektifitas dan efisiensi pelaksanaan belajar mengajar di dalam kelas.

\section{DAFTAR PUSTAKA}

Abdurrahman, M. (2009). Pendidikan Bagi Anak Berkesulitan Belajar. Jakarta: Pusat Perbukuan Departemen Pendidikan \& Kebudayaan dan PT. Rieneka Cipta.

Amir, T. (2009). Inovasi Pendidikan Melalui Problem Based Learning. Jakarta: Kencana.

Arikunto, S. (2008). Prosedur Penelitian Suatu Pendekata Praktik Edisi Revisi VI. Jakarta : Rineka Cipta.

Arrends, R.I. (2008). Learning To Teach.Yogyakarta: Pustaka Pelajar.

Arsyad, A. (2010). Media Pembelajaran. Jakarta: Rajawali Pers.

Asyhar, R. (2011). Kreatif Mengembangkan Media Pembelajaran. Jakarta : Gaung Persada Press.

Bloom, B.S. (1976). Human Teory of School Learning. New York: Mc Graw Hill Book Company.

Deporter, B dan Hanarcki. (2011). Quantum Learning. Bandung :Kaifa.

Dick, W and Carey L. (2005). The Systematic Design Of Instruction. Boston : Pearson.

Dimyati dan Mudjiono, (2009). Belajar Dan Pembelajaran, Jakarta: Rineka Cipta.

Dryden dan Jeannette. (2001). Revolusi Cara Belajar: The Learning Revolution. Bandung: Kaita.

Gagne, R.M dan Briggs, L.J. (1979). Principles Of Instructional Design. New York : Holt Rinehart \& Winston.

Gunawan. (2004). Born To Be a Genius.Jakarta: Gramedia

Ide, P. (2009). Menyeimbangkan Otak Kiri Dan Otak Kanan. Jakarta : Gramedia

Isjoni. (2009). Pembelajaran Kooperatif. Yogyakarta : Pustaka Pelajar

Joyce, B.W.M, dan Calhoun, E. (2009). Models Of Theaching (Edisi Delapan). Yogyakarta : Pustaka Pelajar

Miarso, Y. (2009). Menyemai Benih Teknologi Pendidikan. Jakarta : Kencana

Nasution, S. 2005. Berbagai Pendekatan Dalam Proses Belajar dan Mengajar. Jakarta : Bumi Aksara.

Purwanto M. (2011). Psikologi Pendidikan. Bandung : Remaja Rosdakarya. 
Reigeluth, C.M. (1983). Instructional Design Theories and Models. Lawrence Erbtum Associaties. New Yersey.

Sanjaya, W. (2008). Perencanaan dan Desain Sistem Pembelajaran. Jakarta : Kencana.

Sanjaya, W. (2010). Strategi Pembelajaran Berorientasi Standar Proses Pendidikan. Jakarta : Prenada Media Group.

Solihatin, E., dan Raharjo. (2008). Cooperative Learning Analisis Model Pembelajaran IPS. Jakarta : Bumi Aksara.

Sudjatmiko, dan Nurlaili, L. (2003). Kurikulum Berbasis Kompetensi.Jakarta: Departemen Pendidikan Nasional.

Sumiati dan Asra.(2007). Metode Pembelajaran. Bandung : CV. Wacana Prima.

Suparman, A. (2001). Desain Instruksional. Jakarta. PAU Dikti Depdikpud.

Trianto. (2009). Mendesain Model Pembelajaran Inovatif -Progresif. Jakarta: Kencana Prenada Media Group.

Warsita, B. (2008). Teknologi Pembelajaran. Jakarta: Rieneka Cipta. 